\title{
Receptor Sizes and Its Effect on Lightning Protection of Modern Wind Turbines
}

\author{
Godson I. Ikhazuangbe ${ }^{1, *}$, K. M. Begam ${ }^{1}$, Chandima Gomes ${ }^{2}$ \\ and Anandan Shanmugam ${ }^{1}$ \\ ${ }^{1}$ Department of Electrical and Electronic Engineering, \\ The University of Nottingham Malaysia Campus, 43500, \\ Semenyih, Selangor, Malaysia \\ ${ }^{2}$ Department of Electrical and Electronic Engineering, \\ University Putra Malaysia, 43400, \\ Serdang, Selangor, Malaysia \\ *Corresponding Author: kecx4iga@nottingham.edu.my
}

Received 16 August 2017; Accepted 24 November 2017;

Publication 18 December 2017

\begin{abstract}
Wind turbine can be destroyed when not adequately protected by the receptor. According to recent research, the size of the receptor plays a very important role in its efficiency. The effect of receptor size has not been well considered in literature and standards. This paper investigates six receptor sizes $(10 \mathrm{~mm}$, $15 \mathrm{~mm}, 20 \mathrm{~mm}, 25 \mathrm{~mm}, 30 \mathrm{~mm}$ and $35 \mathrm{~mm}$ receptor diameters), encompassing adopted sizes in literature. As the blade is rotated, the interception efficiency of various receptor sizes is evaluated on a modern wind turbine. The vertical tri-pole cloud charge model developed with finite element analysis is used to study the maximum electric field strength required for the initiation of upward leader from the blade surfaces. The interception efficiency of each receptor size is evaluated by comparing the maximum electric field strength. The results of the point of initiation of upward leader match well with those obtained by experimental measurements from lightning discharge attachments.
\end{abstract}

Keywords: Simulation, Lightning protection, Receptor size, Wind turbine.

Journal of Green Engineering, Vol. 7.3, 401-420.

doi: 10.13052/jge1904-4720.734

This is an Open Access publication. (c) 2017 the Author(s). All rights reserved. 


\section{Introduction}

Lightning is a worldwide problem, Germany alone reported 393 events of lightning damage to wind turbines between 1992 and 1995 [1]. When lightning attach to the blade surface instead of the air-terminal, the blade and sometimes, the entire wind turbine can be destroyed resulting in downtimes, loss of wind turbine, and expensive cost of repair. Modern wind turbines with increasing height have become more vulnerable to increased number of lightning strikes. When lightning strikes a wind turbine, the resultant damage could be by direct strike or by producing electric and magnetic fields that can induce voltages in local wiring.

Damages vary in magnitude, more severe with unprotected blades and can be eliminated or reduced by efficient protection with air termination. Lightning protection systems (LPS) are usually installed on modern wind turbines [2-4]. It encompasses; a network of air terminals, bonding conductors, and ground electrodes, designed to provide a low impedance path to ground for potential lightning strikes [5]. There are a number of lightning protection methods used on wind turbines, these includes; Receptors, Metallic Cap, Metallic Conductor on the Blade Tip, Mesh, Ring Electrode [2] and the Backside Electrode [3] methods. However, modern wind turbines are predominantly protected with the receptor method. More also, multiple receptors on the blade has been a focus of research but the single-receptor method has remained the preferred choice. Therefore, only the single-receptor method is considered in this paper.

The receptor though effective [6], also failed in so many instances as mentioned in $[7,8]$. The efficiency of the receptor is dependent on its interception proficiency which is its ability to intercept a lightning stroke. This strongly dependent on the size of the receptors [9]. The effect of receptor size has not been well considered in literature and standards. An attempt was made by Wang et al. [10], however, only the shape (tip shape receptor, also referred to as metallic cap and disk shape receptor) were considered and not the various sizes.

Since there are no standard governing receptor sizes, choices are made randomly by researchers. for instance; Abd-Elhady et al. [11], used $20 \mathrm{~mm}$ in diameter; Wang et al. [10], used $0.2 \mathrm{~m}$ and $0.3 \mathrm{~m}$ radius; Naka et al. [12], used $25 \mathrm{~mm}$ in diameter; in IEC61400-24, $15 \mathrm{~mm}$ in diameter was applied; Peesapati and Cotton [13], used $10 \mathrm{~mm}$ in diameter; Minowa et al. [3], used $20 \mathrm{~mm}$ in diameter; Shindo et al. [6], used $35 \mathrm{~mm}$ in diameter; Yokoyama et al. [14], used $25 \mathrm{~mm}$ in diameter and Danoon et al. [15], used $30 \mathrm{~mm}$ in diameter. 
This is not healthy for an efficient lightning protection because the results are affected as the size of the receptor has been found to significantly affect its efficiency. It is therefore necessary to harmonize on the most efficient receptor size for an efficient lightning protection of wind turbines.

In this paper, the extended vertical tri-pole thundercloud model in our previous paper [16] is used to evaluate the maximum electric field strength required for the initiation of upward leader from a modern wind turbine: Vestas V100. The numerical model is developed with COMSOL Multiphysics software. The receptor size is evaluated and optimized by comparing the electric field strength as the receptor size is changed and the blade is rotated. Six receptor sizes $(10 \mathrm{~mm}, 15 \mathrm{~mm}, 20 \mathrm{~mm}, 25 \mathrm{~mm}, 30 \mathrm{~mm}$ and $35 \mathrm{~mm}$ receptor diameters), encompassing adopted sizes in literature are investigated. The point of upward leader inception is predicted by the magnitude of the electric field strength. The paper is organized as follows: Section 2 deals with design model, while Section 3 contains results and discussions, Section 4 concludes the paper.

\section{Design Model}

Software modelling of lightning attachment to wind turbines has recently gained attention, with many research works focused on downward propagating lightning. Nevertheless, a few work, done on upward propagating lightning (Particularly due to electric fields from winter clouds developed at lower altitudes) has shown that apart from the fact that tall wind turbine can increase the number of lightning strike, due to rotation, turbines are triggering their own lightning [17-19], indicating that large portion of the lightning that attach to a wind turbine are upward initiated. This type of lightning are majorly influenced by the slowly increasing electric field with a rise rate lower than $1 \mathrm{KV} / \mathrm{m} / \mathrm{s}$ [20], and the formation is dominated by the electric field distribution and the wind turbine geometry. The stepped leader position influence is removed. Therefore, the analysis in this paper only involves upward lightning strike.

The thundercloud structure used in this paper is detailed in our previous paper [16], it consist of a vertical tri-pole. In the simulation, the three charges of $+40 \mathrm{C},-40 \mathrm{C}$ and $3 \mathrm{C}$ are placed at height of 12,7 and $2 \mathrm{~km}$ from the ground respectively and modelled as spheres of radii $900 \mathrm{~m}$ for the $40 \mathrm{C}$ charges and $150 \mathrm{~m}$ for the charge of $3 \mathrm{C}[13,21]$. The size of the spheres is such that during meshing, the accuracy of the electric field in the area of interest within the model is ensured. 
As was shown in [16], the vertical tri-pole model is used to create an ambient field representing uniform electric field due to cloud charge distribution at $200 \mathrm{~m}$ above ground. A uniform electric field produced by a plane electrode located $200 \mathrm{~m}$ above the ground is then applied on the wind turbine model. The electric field at ground from the vertical tri-pole thundercloud charge coincides with that in [21] with maximum ambient field of just over $5 \mathrm{kV} / \mathrm{m}$. This is used in this paper and an upward-directed electric field is defined as positive [21]. In the simulation, the information from the cloud model is combined with the wind turbine model. The magnitude of the applied electric field is $1 \mathrm{MV} / \mathrm{m}$.

A vista wind turbine model V100 is used. It is a horizontal axis wind turbine with three blades, and has the following properties; $2 \mathrm{MW}$ rated power, $100 \mathrm{~m}$ rotor diameter, swept area of $7.854 \mathrm{~m}^{2}$ and a $49 \mathrm{~m}$ long blade. Details of the wind turbine model, the receptor and their parameters are shown in [16]. The model is shown in Figure 1.

Blade in the vertical position used in the investigation referred here as blade A is shown in Figure 2.

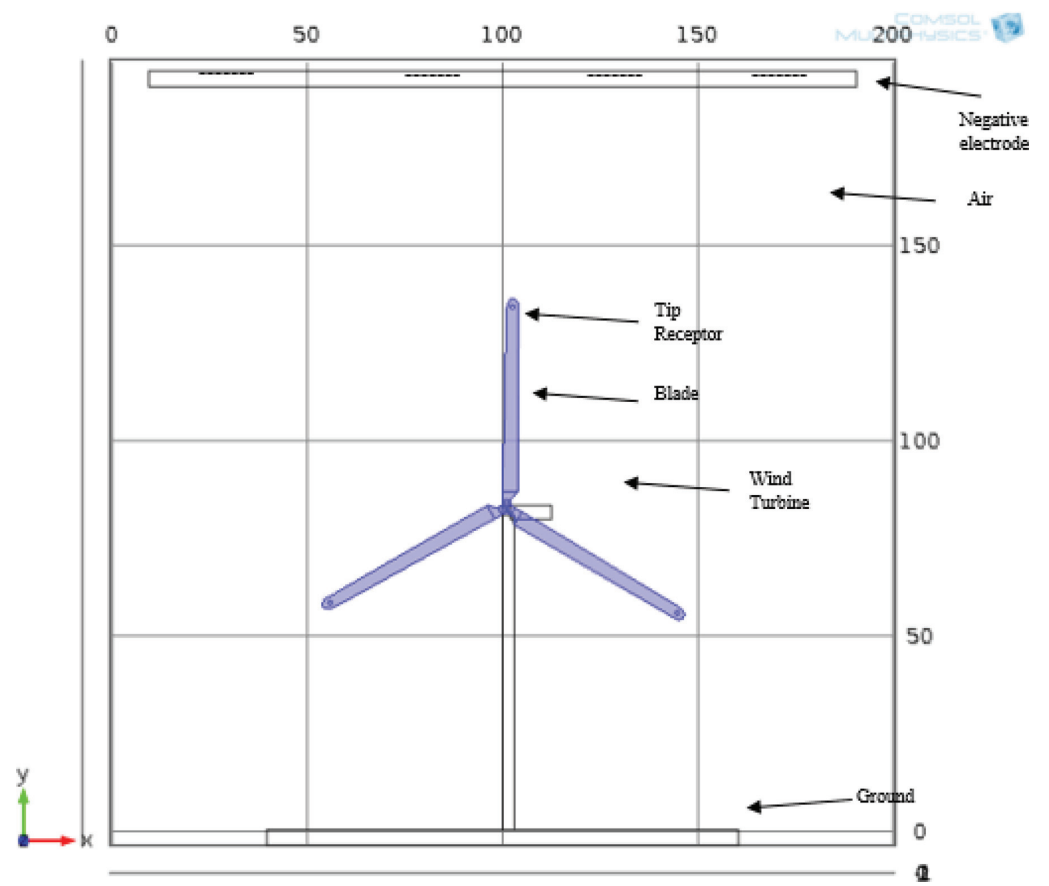

Figure 1 Full scale wind turbine model showing blades (blue), electrode and receptor. 
Six receptor sizes $(10 \mathrm{~mm}, 15 \mathrm{~mm}, 20 \mathrm{~mm}, 25 \mathrm{~mm}, 30 \mathrm{~mm}$ and $35 \mathrm{~mm}$ receptor diameters) (Figure 3), are applied on the wind turbine model to investigate the effect of receptor size on initiation of upward leader. In each case, the blade is rotated through $-60,-30,0,30$ and 60 degrees from the vertical position. The receptor is placed $1.5 \mathrm{~m}$ from the blade tip as recommended in [16]. In this paper, the blade in the vertical position in Figure 1 is referred to as blade A. values obtained from the blade tip, leading edge, trailing edge and the receptor tip for blade A only are provided in this paper.

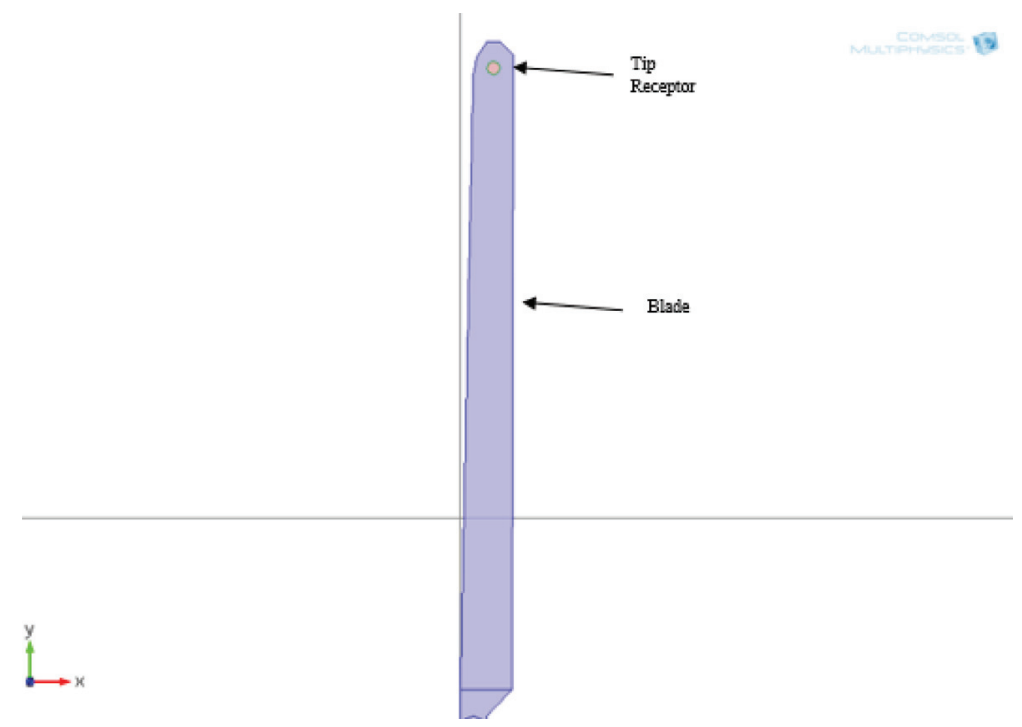

Figure 2 Blade in the vertical position used in the investigation. It is referred here as blade A.

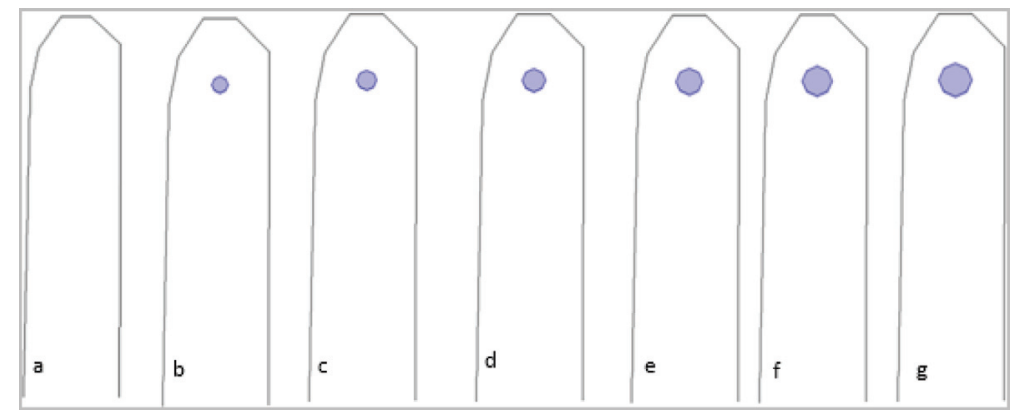

Figure 3 Different receptor sizes: (a) No receptor (b) $10 \mathrm{~mm}$; (c) $15 \mathrm{~mm}$; (d) $20 \mathrm{~mm}$; (e) $25 \mathrm{~mm}$; (f) $30 \mathrm{~mm}$ and (g) $35 \mathrm{~mm}$ diameters. 
The major interest in this paper is to investigate the interception efficiency of various receptor sizes. The computational domain in COMSOL Multiphysics software is shown in Figure 1 . The peak current $I_{\text {peak }}$ applied is $30 \mathrm{kA}$ [22], selected because it represents the general situation of lightning strikes.

\section{Results and Discussion}

This section presents the results obtained from different receptor sizes and discussions. The electric field strength on the rotated blade (A) surface is shown. The locations with higher electric field strength are considered to have higher possibility of inception of upward leader. Obtained results are compared and plotted for the blade tip, leading edge, trailing edge and the receptor tip. The most efficient receptor size is the one with highest electric field on the receptor and minimum at the tip, leading and trailing edges.

In evaluating the effect of receptor sizes on the electric field strength, the simulation is conducted on the wind turbine, first without receptor and then as the blade is rotated, the receptor size is changed. The simulated model is shown in Figure 4.

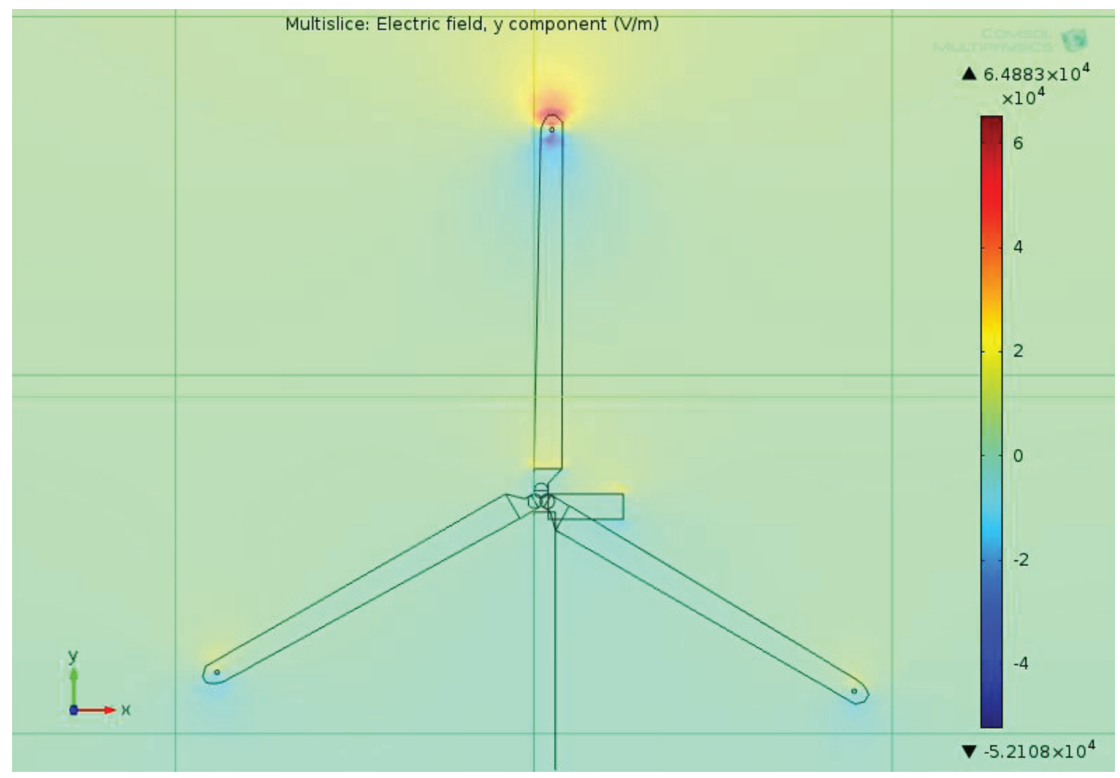

Figure 4 Simulated model showing electric field strength and leader inception. 


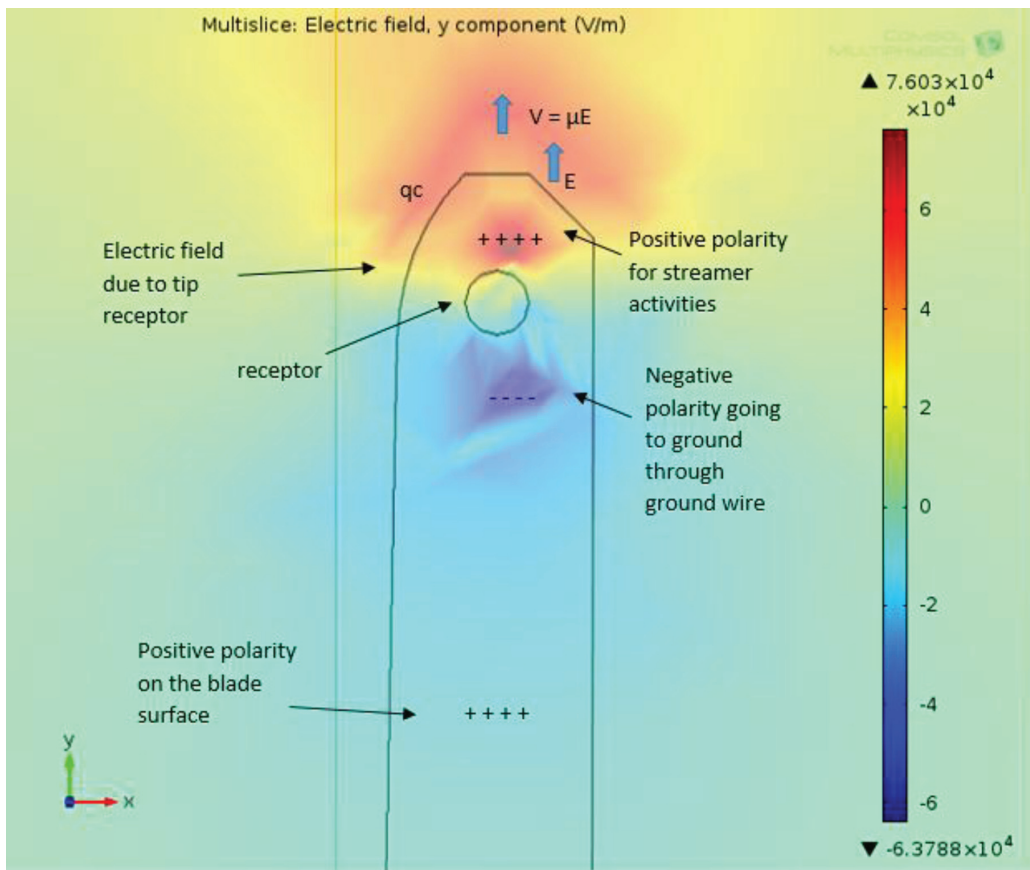

Figure 5 Activities around the receptor preceding leader initiation [16].

In other to protect the wind turbine, the receptors are activated and field enhancement is seen as shown above. Detailed activities around the receptor is shown in Figure 5, these include; the upward positive polarity for streamer activities; positive polarity on the blade surface; the negative polarity going to ground through ground wire; and the produced corona charge (qc) which lowers the electric field on the tip impeding the occurrence of a streamer.

Blade $\mathrm{A}$ is rotated from -60 to +60 degrees from the vertical position and the maximum electric field distribution is shown which appears higher at the tip than other parts of the blade, this supports experimental results in [23], indicating more vulnerability of the blade tip. In this paper, the locations with higher electric field strength are considered to have higher likelihood of inception of upward leader.

Figure 6 shows the simulation for different receptor sizes used in the comparison of the maximum electric field strength distribution: (a) $10 \mathrm{~mm}$; (b) $15 \mathrm{~mm}$; (c) $20 \mathrm{~mm}$; (d) $25 \mathrm{~mm}$; (e) $30 \mathrm{~mm}$ and (f) $35 \mathrm{~mm}$ diameters respectively. 
Table 1 Maximum electric field strength distribution $(\mathrm{kV} / \mathrm{m})$

\begin{tabular}{|c|c|c|c|c|}
\hline Angle from Vertical & Blade Tip & Leading Edge & Trailing Edge & Receptor \\
\hline \multicolumn{5}{|c|}{ Receptor $10 \mathrm{~mm}$ Diameter } \\
\hline-60 & 20.12 & 36.25 & 0.43 & 60.78 \\
\hline-30 & 43.96 & 42.64 & 21.93 & 121.0 \\
\hline 0 & 58.29 & 26.93 & 45.70 & 193.0 \\
\hline 30 & 45.03 & 2.04 & 51.43 & 135.0 \\
\hline 60 & 21.27 & -14.83 & 37.41 & 61.35 \\
\hline \multicolumn{5}{|c|}{ Receptor $15 \mathrm{~mm}$ Diameter } \\
\hline-60 & 20.45 & 36.58 & -0.69 & 43.79 \\
\hline-30 & 47.09 & 42.87 & 25.37 & 79.96 \\
\hline 0 & 57.54 & 28.03 & 52.57 & 89.22 \\
\hline 30 & 44.10 & 4.02 & 57.29 & 59.87 \\
\hline 60 & 20.51 & -13.09 & 41.06 & 14.76 \\
\hline \multicolumn{5}{|c|}{ Receptor $20 \mathrm{~mm}$ Diameter } \\
\hline-60 & 20.95 & 36.66 & -0.15 & 40.49 \\
\hline-30 & 44.87 & 40.81 & 25.36 & 74.01 \\
\hline 0 & 57.49 & 27.58 & 52.17 & 82.63 \\
\hline 30 & 44.93 & 2.16 & 57.83 & 56.58 \\
\hline 60 & 19.88 & -14.05 & 39.65 & 13.60 \\
\hline \multicolumn{5}{|c|}{ Receptor $25 \mathrm{~mm}$ Diameter } \\
\hline-60 & 18.22 & 38.36 & 0.18 & 32.83 \\
\hline-30 & 41.18 & 42.18 & 20.91 & 82.58 \\
\hline 0 & 55.01 & 28.06 & 44.47 & 98.13 \\
\hline 30 & 46.35 & 1.04 & 53.38 & 79.29 \\
\hline 60 & 20.37 & -15.01 & 36.93 & 33.74 \\
\hline \multicolumn{5}{|c|}{ Receptor $30 \mathrm{~mm}$ Diameter } \\
\hline-60 & 18.33 & 38.81 & -0.06 & 31.23 \\
\hline-30 & 43.33 & 45.64 & 20.90 & 70.08 \\
\hline 0 & 55.96 & 28.83 & 43.62 & 93.47 \\
\hline 30 & 46.87 & 2.10 & 53.07 & 83.28 \\
\hline 60 & 20.72 & -14.55 & 37.73 & 31.62 \\
\hline \multicolumn{5}{|c|}{ Receptor $35 \mathrm{~mm}$ Diameter } \\
\hline-60 & 19.77 & 39.74 & -0.66 & 29.24 \\
\hline-30 & 41.75 & 43.88 & 21.82 & 68.24 \\
\hline 0 & 56.05 & 29.31 & 46.48 & 88.84 \\
\hline 30 & 48.88 & 1.27 & 56.42 & 68.55 \\
\hline 60 & 21.12 & -14.36 & 38.30 & 30.84 \\
\hline
\end{tabular}



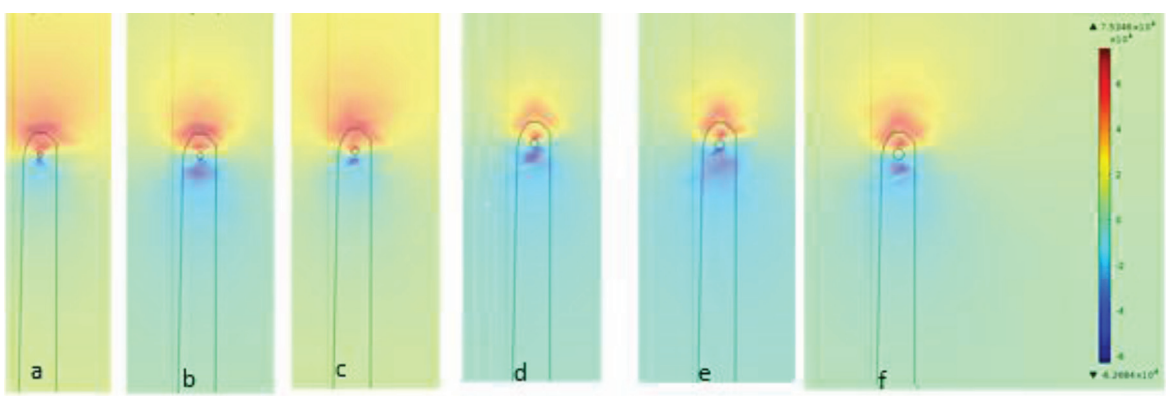

Figure 6 Receptor sizes and their various maximum electric field strength distribution: (a) $10 \mathrm{~mm}$; (b) $15 \mathrm{~mm}$; (c) $20 \mathrm{~mm}$; (d) $25 \mathrm{~mm}$; (e) $30 \mathrm{~mm}$ and (f) $35 \mathrm{~mm}$ diameters respectively.

The results are shown in Table 1 and plotted in Figures 7-12.

1. Receptor $10 \mathrm{~mm}$ diameter

\section{$10 \mathrm{~mm}$}

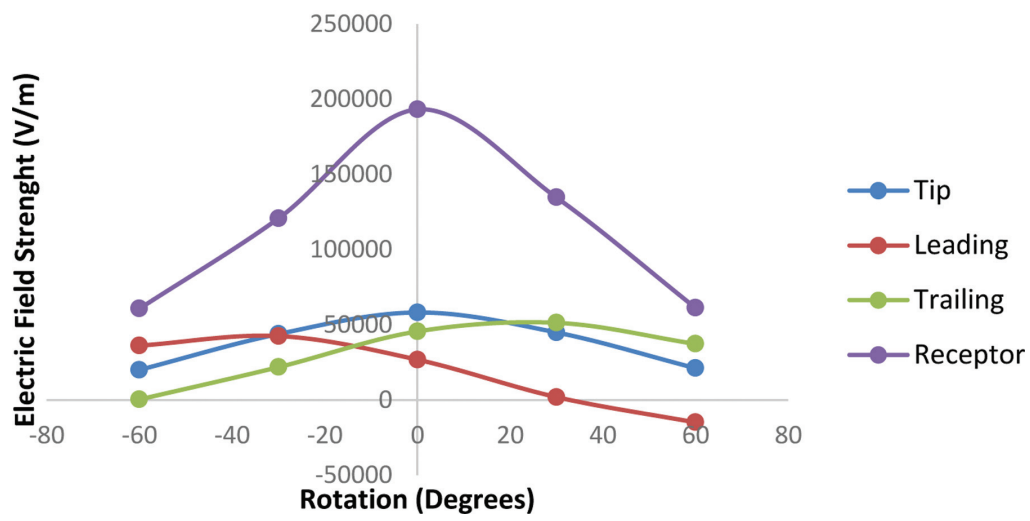

Figure 7 Maximum electric field strength distributions due to $10 \mathrm{~mm}$ diameter receptor as blade $\mathrm{A}$ is rotated.

A receptor $10 \mathrm{~mm}$ in diameter is used on the model, the simulation result is shown in the plot above (Figure 7). The electric field distribution on the blade is shown. As expected, it is highest at the receptor and as such, leader will incept from it first followed by other part of the blade in the sequence as depicted by the plot. 
2. Receptor $15 \mathrm{~mm}$ diameter

\section{$15 \mathrm{~mm}$}

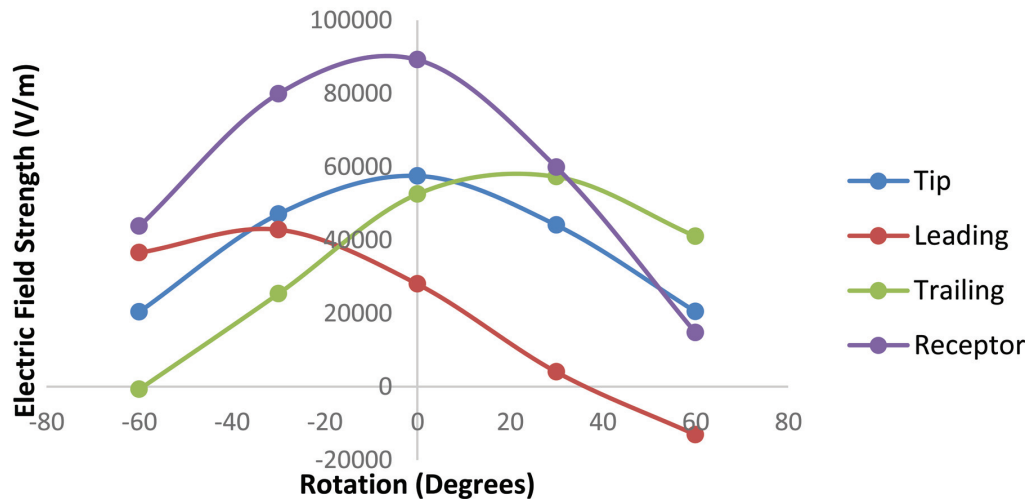

Figure 8 Maximum electric field strength distributions due to $15 \mathrm{~mm}$ diameter receptor as blade $\mathrm{A}$ is rotated.

The receptor size is changed to $15 \mathrm{~mm}$ and the process is repeated, obtained result is plotted in Figure 8. It is observed that the change in receptor size has significantly affected the result as shown by the plot.

3. Receptor $20 \mathrm{~mm}$ diameter

\section{$20 \mathrm{~mm}$}

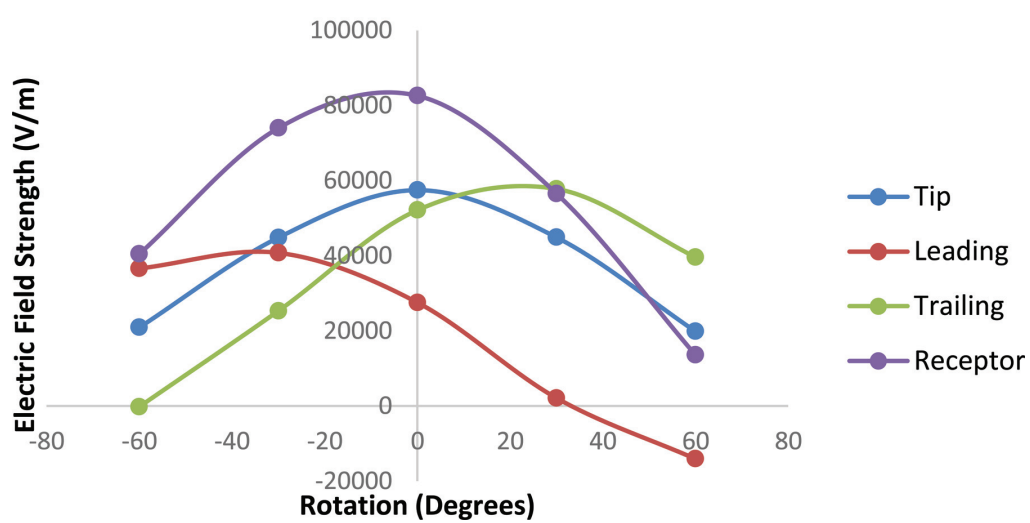

Figure 9 Maximum electric field strength distributions due to $20 \mathrm{~mm}$ diameter receptor as blade $\mathrm{A}$ is rotated.

As shown in Figure 9 above, the effect of receptor size is seen. In this instance, the size is increased to $20 \mathrm{~mm}$. Here, there is a possibility of leader 
incepting from the trailing edge before the receptor at between 40 and 60 degrees.

4. Receptor $25 \mathrm{~mm}$ diameter

\section{$25 \mathrm{~mm}$}

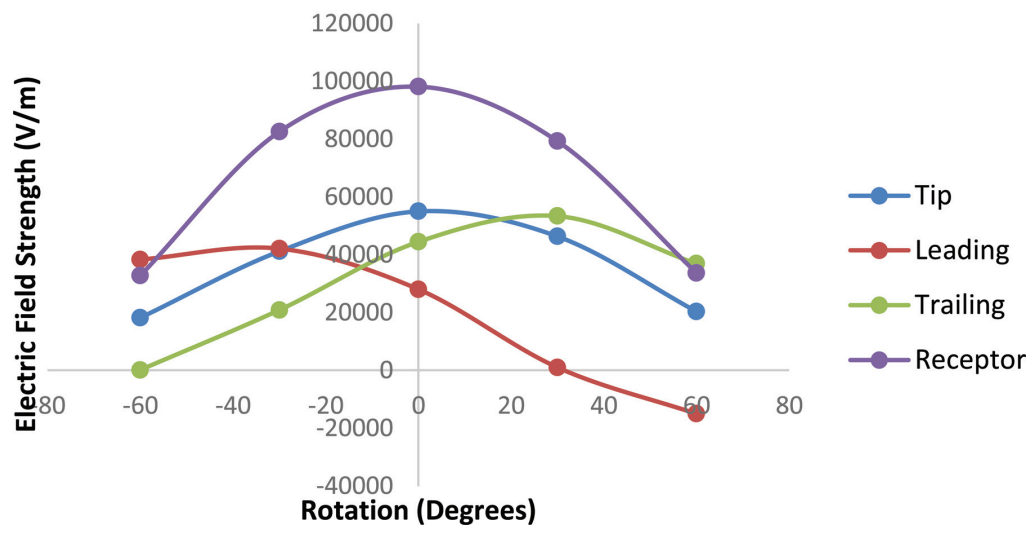

Figure 10 Maximum electric field strength distributions due to $25 \mathrm{~mm}$ diameter receptor as blade $\mathrm{A}$ is rotated.

The receptor size is increased to $25 \mathrm{~mm}$ and the effect is shown in Figure 10 above.

5. Receptor $30 \mathrm{~mm}$ diameter

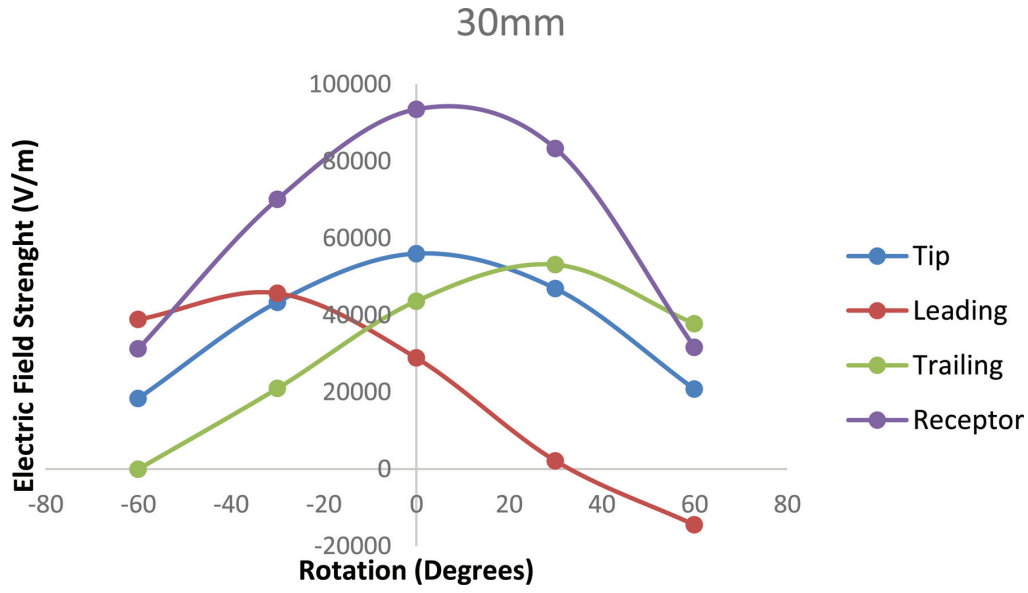

Figure 11 Maximum electric field strength distributions due to $30 \mathrm{~mm}$ diameter receptor as blade $\mathrm{A}$ is rotated. 


\section{G. I. Ikhazuangbe et al.}

Similarly, the receptor size is increased to $30 \mathrm{~mm}$ diameter and the effect is shown in Figure 11.

6. Receptor $35 \mathrm{~mm}$ diameter

\section{$35 \mathrm{~mm}$}

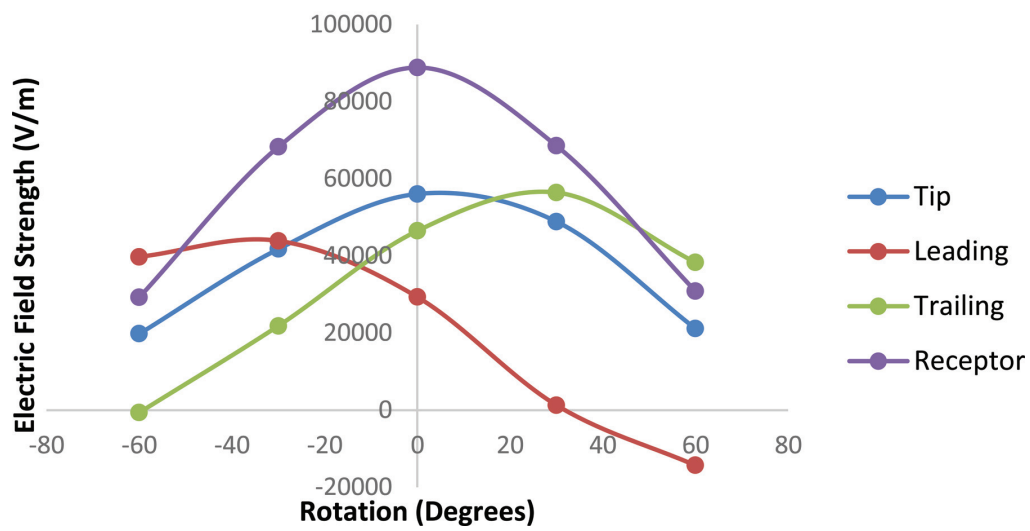

Figure 12 Maximum electric field strength distributions due to $35 \mathrm{~mm}$ diameter receptor as blade $\mathrm{A}$ is rotated.

Finally, the receptor size is increased to $35 \mathrm{~mm}$ in diameter. The result is shown above in Figure 12 in this case, it is also observed that it is possible for leader to incept from other part of the blade before the receptor.

The comparison for various receptor sizes is shown in; (Figure 13) for blade tip, (Figure 14) for leading edge, and (Figure 15) for trailing edge.

7. Comparison

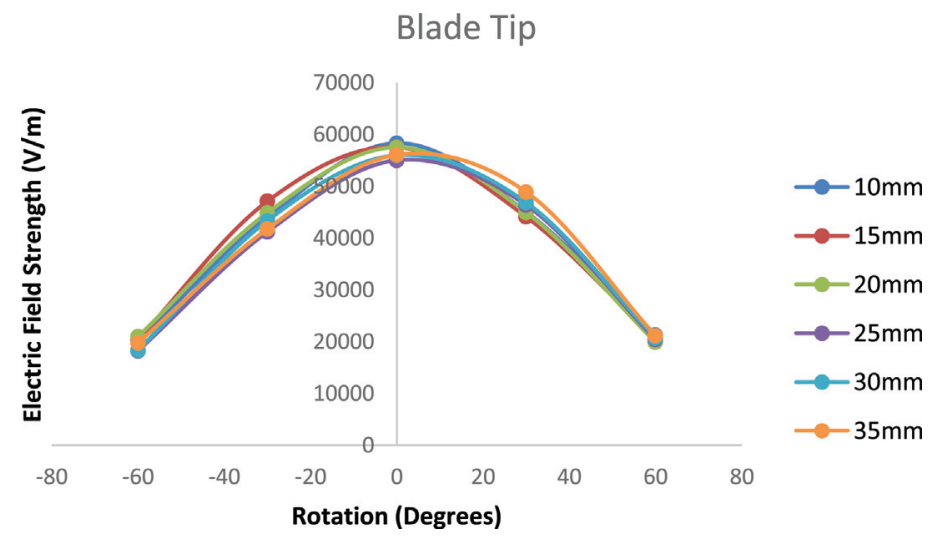

Figure 13 Comparison for various receptor sizes at the blade tip. 


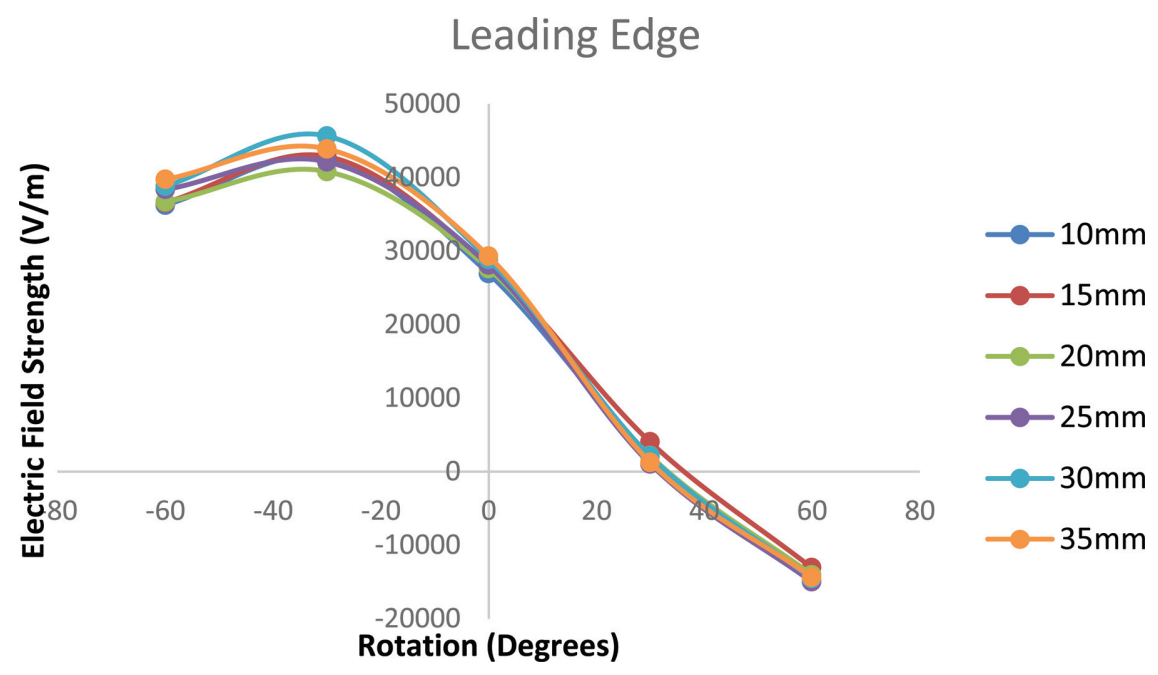

Figure 14 Comparison for various receptor sizes at the leading edge.

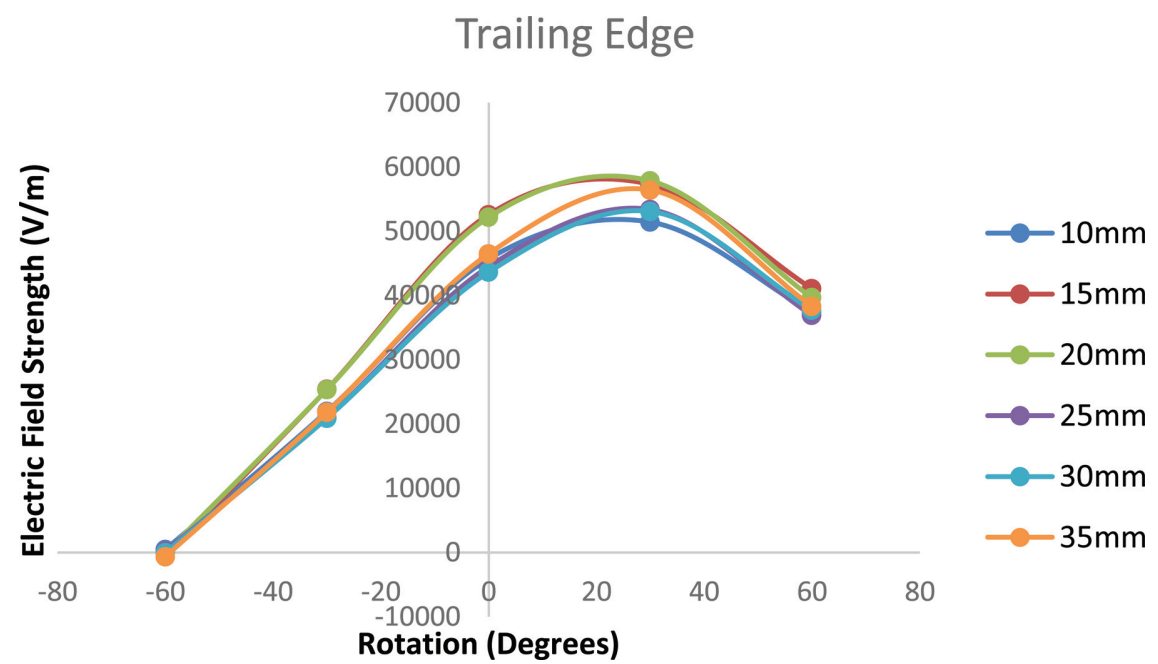

Figure 15 Comparison for various receptor sizes at the trailing edge.

Figure 16 shows the comparison of maximum electric field strength on the receptor for various receptor sizes.

It is desirable, for efficient lightning protection that the electric field distribution at the blade tip, leading edge, trailing edge and the entire wind turbine surface be kept to a minimum due to the presence of the receptor, 


\section{Receptor Tip}

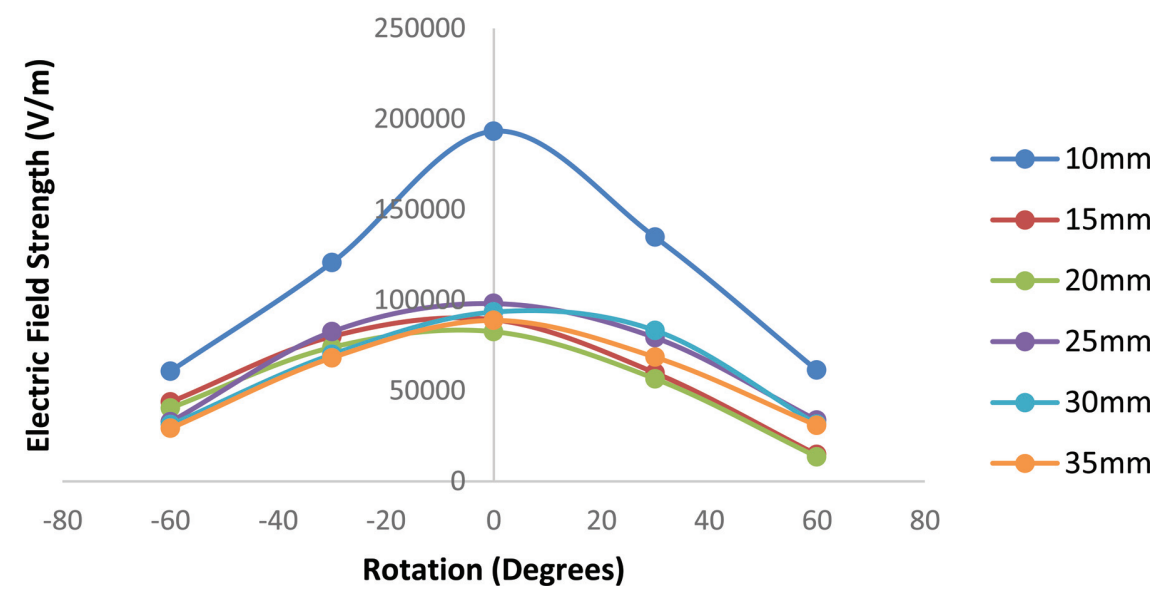

Figure 16 Comparison for various receptor sizes at the receptor tip.

whereas, most significantly, it should be maximum on the receptor so that leader will incept from the receptor first before any other part of the wind turbine. The receptor size with the highest maximum electric field on the receptor is $10 \mathrm{~mm}$ diameter as shown above in Figure 16.

As discussed in [16], the negative polarity going to ground through ground wire as shown in Figure 5 is usually confined to the ground wire and not on the surface of the blade, therefore, only the positive parts of various plots are relevant.

Experimental validation of the extended vertical tri-pole model used in this study as compared with results from Elhady et al. [11] is shown in [16]. Obtained results of maximum electric field strength agrees with experimental data on points of leader attachment and upward leader initiation points. It also corroborated that the blade positions significantly affect the lightning attachment manner as well as the performance of the blade lightning protection systems. The maximum electric field strength locations on the trailing edge are higher than that of the leading edge which agrees with experimental result that the blade trailing edge attracts discharges more times than the blade leading edge.

It is found that $10 \mathrm{~mm}$ receptor diameter presents the highest electric field strength on the receptor than other receptor sizes. Also, relatively, the electric field distribution at the blade tip, leading edge, trailing edge for $10 \mathrm{~mm}$ receptor diameter is lower than that of other sizes. This indicates that $10 \mathrm{~mm}$ receptor 
diameter will allow leader to be initiated from the receptor before any other part of the blade or wind turbine and as a result prevent damage. This receptor size will therefore provide higher protection efficiency than other receptor sizes and is therefore recommended. $10 \mathrm{~mm}$ is the smallest amongst the sizes considered and would be thought least in withstanding high current, however, it has been shown in literature that this size is adequate for an average peak stroke current and if need be, this can be improved by increasing the diameter of the down conductors. With proper scaling, findings in this paper can be extended to other wind turbine sizes.

\section{Conclusion}

This paper investigates the effect of receptor size on wind turbine lightning protection systems. The extended vertical tri-pole model has been used to create a uniform electric field using Comsol Multiphysics. This has been applied to a Vestas V100 wind turbine to study the variations in maximum electric field strength required for the initiation of upward leader. The receptor size is studied by comparing the electric field strength. The applied model was initially validated by experimental data.

Results show that receptor size $10 \mathrm{~mm}$ diameter provides higher protection efficiency than other sizes and is therefore recommended for efficient lightning protection of modern wind turbines. Further work will include polluted blade condition as in the case of offshore wind turbines.

\section{References}

[1] Durstewitz, M., Ensslin, C., Hoppe-Kilpper, M., and Rohrig, K. (1996). "External conditions for wind turbine operation-results from the German'250 MW wind' programme," in European Union Wind Energy Conference, 20-24.

[2] Zavareh, H. T. (2012). "Wind turbines protection against the lightning struck using a combined method," in Renewable Energy and Distributed Generation (ICREDG), 2012 Second Iranian Conference, 51-54.

[3] Minowa, M., Ito, K., Sumi, S. I., and Horii, K. (2012). "A study of lightning protection for wind turbine blade by using creeping discharge characteristics," in Lightning Protection (ICLP), 2012 International Conference, 1-4. 
[4] Ayub, A. S., Siew, W. H., and MacGregor, S. J. (2011). "Lightning protection of wind turbine blades - An alternative approach," in Lightning (APL), 7th Asia-Pacific International Conference, 941-946.

[5] Staszewski, Ł. (2010). "Lightning Phenomenon - Introduction and Basic Information to Understand the Power of Nature," in International Conference Environment and Electrical Engineering, University of Technology, Wroclaw, Poland.

[6] Shindo, T., Asakawa, A., and Miki, M. (2011). "Characteristics of lightning strikes on wind turbine blades. Experimental study of the effects of receptor configuration and other parameters," Electrical Engineering in Japan, 176, 8-18.

[7] Yoh, Y., and Shigeru, Y. (2011). Proposal of lightning damage classification to wind turbine blades. In Lightning (APL), 2011 7th Asia-Pacific International Conference, 368-371. IEEE.

[8] Yokoyama, S. (2011). Lightning protection of wind turbine generation systems. In Lightning (APL), 7th Asia-Pacific International Conference, 941-947. IEEE.

[9] International Electrotechnical Commission [IEC] (2010). 61400-24 "Wind turbine," Part 24: Lightning protection. Geneva: IEC.

[10] Wang, Y., and Hu, W. (2017). Investigation of the effects of receptors on the lightning strike protection of wind turbine blades. IEEE Transactions on Electromagnetic Compatibility, 59, 1180-1187. Doi: 10.1109/TEMC.2016.2647260

[11] Abd-Elhady, A. M., Sabiha, N. A., and Izzularab, M. A. (2014). Experimental evaluation of air-termination systems for wind turbine blades. Electric Power Systems Res. 107, 133-143. Doi: 10.1016/j.epsr.2013.10.002

[12] Naka, T., Vasa, N. J., Yokoyama, S., Wada, A., and Arinaga, S. (2006). "Experimental studies on lightning protection design for wind turbine blades," in Proceedings of European Wind Energy Association (EWEC), Athen, Greece.

[13] Peesapati, V., and Cotton, I. (2009). "Lightning protection of wind turbines-A comparison of real lightning strike data and finite element lightning attachment analysis," in International Conference on Sustainable Power Generation and Supply, SUPERGEN'09, 1-8.

[14] Yokoyama, S. (2013). Lightning protection of wind turbine blades. Electric Power Sys. Res. 94, 3-9. Doi: 10.1016/j.epsr.2012.07.017 
[15] Danoon, L., El-Makadema, A., and Brown, A. (2014). On the integration of lightning protection with stealth coated wind turbine blades. Wind Energy, 17, 1577-1585. Doi: 10.1002/we.1652

[16] I. Godson, K. M. Begam, G. Chandima, S. Anandan, and N. Kenneth, "Optimum receptor location for efficient lightning protection of modern wind turbines," International Journal of Simulation Systems, Science \& Technology, vol. 18, 2017. [will be available online soon].

[17] Wang, D., Takagi, N., Watanabe, T., Sakurano, H., and Hashimoto, M. (2008). Observed characteristics of upward leaders that are initiated from a windmill and its lightning protection tower. Geophys. Res. Lett. 35. Doi: 10.1029/2007GL032136

[18] Rachidi, F., Rubinstein, M., Montanya, J., Bermudez, J. L., Sola, R. R., Sola, G., and Korovkin, N. (2008). A review of current issues in lightning protection of new-generation wind-turbine blades. IEEE Transactions on Industrial Electronics, 55, 2489-2496. Doi: 10.1109/TIE.2007.896443

[19] Montanyà, J., Velde, O., and Williams, E. R. (2014). Lightning discharges produced by wind turbines. J. Geophys. Res.: Atmos. 119, 1455-1462. Doi: 10.1002/2013JD020225

[20] Cooray, V. (2010). Lightning protection. The Institution of engineering and technology. London: The Institution of Engineering and Technology.

[21] Rakov, V. A., and Uman, M. A. (2003). Lightning: physics and effects. Cambridge University Press.

[22] Ancona, D., and McVeigh, J. (2001). Wind turbine-materials and manufacturing fact sheet. Princeton Energy Resources International, $L L C, 19$. Available at: http://www.perihq.com/documents/WindTurbineMaterialsandManufacturing_FactSheet.pdf

[23] Peesapati, V., Cotton, I., Sorensen, T., Krogh, T., and Kokkinos, N. (2011). Lightning protection of wind turbines - a comparison of measured data with required protection levels. IET Renewable Power Generation 5, $48-57$. 


\section{Biographies}

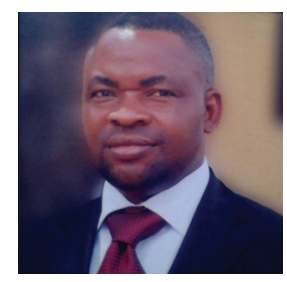

Godson Ivbuobe Ikhazuangbe obtained a BEng degree in Electrical/ Electronic Engineering in 1999 from Ambrose Alli University, Ekpoma, Nigeria and in 2007 he obtained a MTech degree in Electrical/Electronic Engineering (Electrical Power transmission) from Rivers State University of Science and Technology, Portharcourt, Nigeria. He is presently a Ph.D. student at the University of Nottingham. He is a lecturer with Kenule Sarowiwa Polytechnic Bori, Rivers State, Nigeria. Research interest is in Renewable Energy, Electrical power and machines, Wind turbine lightning protection. $\mathrm{He}$ is a resource person to national board for technical education (NBTE) and member of NSE, COREN and IEEE.

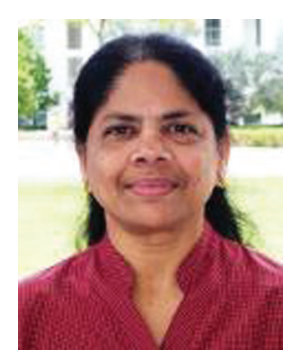

Mumtaj Begam is an Associate Professor in the Department of Electrical and Electronic Engineering, The University of Nottingham, Malaysia. She obtained her B.Sc (Special) from University of Madras and M.Sc (Electronics) from Bharathidasan University, both from India. She also obtained a Bachelor degree in Education (B.Ed.) from Annamalai University, India. She worked in India for a reputed engineering college affiliated to Anna University, Chennai for 17 years in various academic capacities. She received her Ph.D from Multimedia University (Faculty of Engineering), Malaysia for her work on advanced power sources emphasizing Li-ion batteries. She joined the University Teknologi PETRONAS where she worked as an Associate Professor 
prior to joining The University of Nottingham. She has published over ninety papers in refereed journal, international and national conferences. She also serves as an international advisory board member and technical reviewer for journals and conferences.

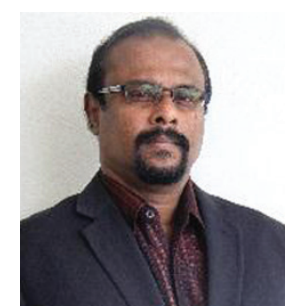

Prof. Dr. Chandima Gomes is a professor of electrical engineering and researcher in high voltage engineering and lightning protection at Universiti Putra Malaysia. He is also an expert in power and energy, electromagnetic interference and compatibility and occupational safety management. Chandima was the founder of the Centre for Electromagnetics and Lightning Protection (CELP), Malaysia and the first Head of the Institute. He has held full-time/adjunct/visiting professorship and lectureship in physics, engineering and meteorology at universities based in Malaysia, Sri Lanka, USA, Australia, Kazakhstan, Pakistan, Zambia and Japan. He is a senior adviser to the National Lightning Safety Institution (NLSI), USA and was the Chief Adviser to African Centers for Lightning and Electromagnetics (ACLENet) based in Uganda. Being an engineering consultant and a business partner for several companies in Asia and Africa, Chandima has 20+ years of international experience in designing lightning protection systems and providing solutions for electromagnetic issues. He is well known at international frontiers as a trainer of trainers in several engineering subjects including, lightning, electrical safety and electromagnetism. He has conducted over 120 training programs in 12 countries so far. Chandima has published over 250 research papers and several books on his expertise. He obtained a First Class Degree in Physics from the University of Colombo in 1993. He has done research for his $\mathrm{PhD}$ (1999) and postdoctoral research on lightning protection and high voltage engineering at Uppsala University, Sweden. 


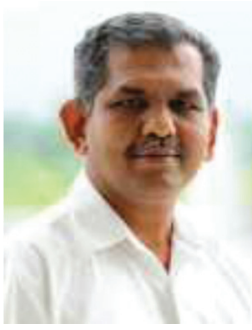

S. Anandan Shanmugam, M.Tech obtained from University of Malaya, currently the director of Mechatronics Engineering at University of Nottingham Malaysia. Has been a medical instrumentation and systems developer with twenty years of experience in teaching engineering and electronic subjects, system interface, special purpose medical product and instrument development, reliability and renewable energy management systems. Consultant in green energy materials and devices. Research and development experiences, mainly in supercapacitor green materials and energy device development. 